\title{
MJN FACTORS RELATED WITH SEXUAL BEHAVIOR IN INTELLECTUAL DISABILITIES IN SLB (SPECIAL NEEDS SCHOOL) DISTRICTS OF BANTUL, YOGYAKARTA
}

\author{
Shulhan Arief Hidayat ${ }^{1 *}$, Sri Hartini ${ }^{2}$, Budi Wahyuni ${ }^{3}$ \\ ${ }^{1}$ STIKes Hutama Abdi Husada Tulungagung, Indonesia \\ 2Department of Child Nursing, Faculty of Medicine Public Health and Nursing, Gadjah Mada University, \\ Indonesia \\ ${ }^{3}$ National Commission on Violence Against Women, Indonesia \\ *Corresponding Author's Email: shulhan@stikestulungagung.ac.id
}

\begin{abstract}
Background: The prevalence of children with intellectual disabilities is reported to be 1-3\% or 30 people out of 1,000 Indonesians. Intellectual disability is characterized by the main characteristic of weak thinking ability. Children with intellectual disabilities do not know what sexuality is, they are less able to adapt to the environment, but they have the same physical development and sexual development characteristics as normal children. Children with intellectual disabilities are at higher risk of having negative sexual behavior compared to normal children. Aim: Knowing the factors (giving parents education about sexuality, adolescent knowledge about sexuality, parenting style, socioeconomic status, exposure to pornographic media, and alcohol consumption) that are related to sexual behavior in adolescents with intellectual disabilities in Bantul Regency SLB (Special Needs Schools), Yogyakarta. Methods: This study was a cross sectional design. The research subjects were all parents and middle school as well as high school intellectual disabilities students in the SLB of Bantul Regency. Research subjects were recruited using consecutive sampling techniques. The instrument used was a questionnaire giving education by parents about sexuality, adolescent knowledge about sexuality, parenting, sexual behavior and screening using peer problem questionnaires. Data analysis was carried out by Person and Independent Sample $T$-test. Results: 64 students (72.7\%) had high risk sexual behavior. There is a significant relationship between exposure to pornographic media $(p=0.000)$ and knowledge of adolescents $(p=0.008)$ with adolescent sexual behavior in intellectual disabilities. There is no significant relationship between alcohol consumption, education provided by parents, parenting and socio-economic status with adolescent sexual behavior of intellectual disabilities. Conclusion: Exposure to pornographic media is the most dominant factor associated with adolescent sexual behavior in intellectual disabilities.
\end{abstract}

Keywords: Intellectual Disability; Youth; Sexual Behavior

\section{INTRODUCTION}

The prevalence of children with intellectual disabilities is reported to be $1-3 \%$ or in other words from 1000 Indonesian population, 30 people suffer from intellectual disabilities (Kementerian Kesehatan, 2014). Data from Riskesdas (2013) showed that a group of school-aged children with intellectual disability was 62,011 children.

Intellectual disability is characterized by the main characteristic of weak thinking or reasoning abilities. WHO (2014) explains that intellectual disability is defined as the abilities that are significantly reduced to understanding new or complex information, to learn, and to apply new skills (intelligence disorders). This, according to Wissink et al. (2015) results in a reduced ability to adapt independently (impaired social function).

Children with intellectual disabilities are less able to adapt to the environment, but they have the same physical development and sexual development characteristics as normal children. Research in Iran shows that children with intellectual disabilities have 
some sexual problems, such as public masturbation, sexual arousal, and severe sexuality against the opposite sex, this behavior is more prominent in adolescents with intellectual disabilities than normal adolescents. About $7.69 \%$ of children with intellectual disabilities were also found to be sexually abused. A similar problem was reported by Tsuda et al., (2017) in his research conducted in Yogyakarta that the most common problem of sexual behavior in children with intellectual disabilities was touching their sexual organs in public areas $(69.1 \%)$, kissing other people in the area public (48.9\%), other behavioral problems namely affection hugs with the opposite sex $(36.2 \%)$.

From the results of a preliminary study conducted on April 6, 2018 at State of SLB 1 Bantul for 5 teachers and 5 parents, showing that teachers and parents saw several children showing sexual behavior such as embracing with the opposite sex, children holding their genitals in public. In fact, according to one teacher there were reported incidents of sexual harassment (rape) on SLBN 1 Bantul alumni. Akrami (2014) explains that there are several factors related to sexual behavior problems both as perpetrators and victims, namely: 1) Increased libido sexuality caused by changes in adolescent hormones. 2) Delaying the age of marriage. 3) There is a prohibition and considers that sex is a taboo thing so that teenagers tend to violate the prohibition. 4) Lack of information about sex because of relationships that are not open between parents and children. 5) Youth associations are now increasingly free. Meanwhile, according to Kellogg (2009) factors that can influence sexual behavior in children are parenting (exposure or frequent viewing of naked family members, shared baths), limited privacy, exposure to easily accessible pornographic material, exposure to sexual acts, adult supervision, physical abuse.

Previous researchers also reported that factors that can influence sexual behavior in disabled youth are the provision of education by parents about sexuality (Atienzo et al., 2009; Wilson et al., 2010; Chalmers, Tyrer \& Aggleton 2006; Clatos \& Asare, 2016; Stein, Kohut, \& Dillenburger, 2017), adolescent knowledge about sexuality (Kim, Park \& Lee, 2018), parenting (Huebner \& Howell, 2003), socio-economic status (Raudsepp, 2007), exposure to pornographic media (Lou et al., 2012, Kaljee et al., 2011), and the influence of alcohol (Muchimba et al., 2013). There were 78 SLB in Daerah Istimewa Yogyakarta (DIY) Province with details of Bantul Regency as many as 20 SLB, Sleman
Regency as many as 29 SLB, Gunung Kidul Regency as many as 12 SLB, Kulon Progo Regency as many as 8 SLB, city of Yogyakarta as many as 9 SLB.

Bantul Regency is one of the regencies in DIY Province with the highest number of junior and senior high school students with intellectual disabilities in DIY Province, namely 120 junior high school students and 59 high school students. Based on the literature search conducted by researchers, there have been no studies on factors related to sexual behavior problems in children with intellectual disabilities in Bantul Regency. This then prompted researchers to examine what factors were related to sexual behavior in adolescents with intellectual disabilities at the SLB in Bantul Regency, Yogyakarta. The purpose of this study was to determine the factors associated with sexual behavior in adolescents with intellectual disabilities in Bantul Regency SLB, Yogyakarta.

\section{METHODOLOGY}

\section{Research Design}

This study was an analytic observational study with a cross sectional design which aimed to study the relationship of independent variables with dependent variables, with measurements taken once and at the same time.

\section{Research Location}

This research was conducted on December 2018 in 4 SLBs of Bantul Regency.

\section{Research Subjects}

Respondents in this study were parents of middle and high school intellectually disabled students in Bantul Regency SLB. The number of respondents in this study was 92 parents and SLB students. The inclusion criteria in this study were parents, middle and high school students who suffered mild and moderate intellectual disabilities based on the letters taken for class determination. The exclusion criteria in this study were intellectual disability students who had multiple disabilities along with intellectual disability and who had peer problems (abnormal).

\section{Instrument}

Instrument used in the research is demographic data questionnaire, parental education questionnaire, parenting questionnaire, adolescent knowledge and adolescent sexual behavior questionnaire. The 
questionnaire of giving education by parents about sexuality consists of 7 domains, each aspect in this questionnaire uses a Likert scale, in the form of a 22 closed statement, the measurement criteria are at least 22 years of age and a maximum of 88 years of age, the higher the respondent's score, the better the education given. The questionnaire of adolescent knowledge about sexuality was compiled by the researchers referring to the adolescent reproductive health education module prepared by Indonesian Family Planning Association (PKBI) and National Population and Family Planning Board (BKKBN), and modified according to the research objectives. The number of questions in this questionnaire is 20 items and there are 3 domains, the types of questions used are open questions with the choice of right or wrong answers, the maximum score is 20 and at least 0 , the higher the respondent's score the better his knowledge. The parenting questionnaire is a closed statement with 27 questions items using a Likert scale, the assessment is based on the percentage of the biggest score of the answer score of each parenting pattern. Sexual behavior questionnaire in the form of a closed statement with a Likert scale totaling 22 statements, the assessment is that the higher the score, the higher the risk of negative sexual behavior. The researcher first tested the questionnaire in 3 SLB. The results of the questionnaire trials revealed that there were 22 items regarding giving education by parents and 22 items of sexual behavior questionnaires were declared valid with $r$ count $>t$ table $(0.227)$. Furthermore, from 25 questions about teen knowledge, there were 20 question items declared valid, 5 invalid question items namely numbers 4,7,10,15 and 18 with $r$ count $<r$ table $(0.227)$. Invalid items in the validity test were issued by the researcher and were not used in this study. Reliability shows that the instruments of giving education by parents about sexuality, and instruments of sexual behavior have good reliability values, with values of 0.773 and 0.847 . For instruments of adolescent knowledge about sexuality the value was 0.435 , meaning that the value of reliability for the instrument is sufficient.

\section{Ethical Considerations}

This research has obtained ethical eligibility requirements from the Ethics Commission of the Faculty of Medicine, Public Health and Nursing (FK-KMK) UGM on December 13, 2018 with no Ref: KE / FK / 1328 / EC/ 2018.

\section{Data Analysis}

Descriptive statistical analysis was used to analyze respondents' characteristics of each variable in the study. The bivariate analysis used was for the relationship of giving parental education and knowledge of adolescents to sexual behavior, the test used was Pearson correlation test. To find out the relationship between parenting style, socioeconomic status, exposure to pornography media and alcohol consumption with sexual behavior, the test used is a comparative test ( $t$ test is not released) hecause of the data. Linear regression is used to determine which factors predominantly influence adolescent sexual behavior in intellectual disabilities.

\section{RESULTS}

Table 1 presents the characteristics of respondents. The results of the analysis of demographic characteristics indicate that the majority of students are late adolescents, they are over 17 years, as many as 41 students $(46.6 \%)$ and the majority are male $(51.1 \%)$. Most students in this study were junior high school students (68.2), the majority of students were with mild intellectual disabilities (65.9\%).

Tabel 1: Data Characteristics of Frequency Distribution of Research Respondents in SLB Bantul Regency $2018(n=88)$

\begin{tabular}{|l|c|c|}
\hline \multirow{2}{*}{ Characteristics of Respondent } & \multicolumn{2}{l|}{ Frequency Distribution } \\
\cline { 2 - 3 } & $\mathrm{f}$ & $\%$ \\
\hline Age & & \\
\hline Early adolescence (11-13) & 8 & 9.1 \\
\hline Middle teens (14-16) & 39 & 44.3 \\
\hline Late teens (>17) & 41 & 46.6 \\
\hline Gender & & \\
\hline Man & 45 & 51.1 \\
\hline Woman & 43 & 48.9 \\
\hline Class & & \\
\hline SMP & 60 & 68.2 \\
\hline SMA & 28 & 31.8 \\
\hline Diagnosis & & \\
\hline Mild intellectual disability & 58 & 65.9 \\
\hline Moderate intellectual disability & 30 & 34.1 \\
\hline
\end{tabular}

Moderate intellectual disability3034.1Soure: Primary Data (2018)

Description: $f$ : frequency; \%: percentage

The results of the analysis in Table 2 show that for the description of adolescent sexual behavior as many as 64 students $(72.7 \%)$ included high risk, while as many as 24 students $(27.3 \%)$ for the category were not at risk.

It can be seen that 56 students who have democratic parenting risk are at high risk of abnormal sexual behavior, as many as 45 students with less socioeconomic status are at high risk of sexual behavior, while as many as 33 students often exposed to pornographic media are at high risk of sexual behavior. 
Tabel 2: Cross Tabulation of Parenting, Socioeconomic Status, Alcohol Consumption, And Exposure to Pornographic Media on the Research Sexual Behavior of Adolescents In SLB Bantul Regency $2018(n=88)$

\begin{tabular}{|c|c|c|c|c|c|}
\hline \multirow{3}{*}{ Variable } & \multicolumn{4}{|c|}{ Sexual Behavior } & \multirow{3}{*}{ Total } \\
\hline & \multicolumn{2}{|c|}{ Not at risk } & \multicolumn{2}{|c|}{ High risk } & \\
\hline & $\mathrm{f}$ & $\%$ & $\mathrm{f}$ & $\%$ & \\
\hline Sexual Behavior & 24 & 27.3 & 64 & 72.7 & \\
\hline \multicolumn{6}{|l|}{ Parenting style } \\
\hline Democratic & 22 & 25.0 & 56 & 63.7 & 78 \\
\hline Non democratic & 2 & 2.3 & 8 & 9.0 & 10 \\
\hline \multicolumn{6}{|c|}{ Socio-economic status } \\
\hline Less & 15 & 17.0 & 45 & 51.2 & 60 \\
\hline Well & 9 & 10.2 & 19 & 21.6 & 28 \\
\hline \multicolumn{6}{|l|}{ Alcohol consumption } \\
\hline Consume & 0 & 0.0 & 9 & 10.2 & 9 \\
\hline Never & 24 & 27.3 & 55 & 62.5 & 79 \\
\hline \multicolumn{6}{|c|}{ Exposure to pornographic media } \\
\hline Often exposed & 1 & 1.1 & 33 & 37.5 & 34 \\
\hline Never & 23 & 26.2 & 31 & 35.2 & 54 \\
\hline
\end{tabular}

Source: Primary Data (2018)

Table 3: Factors Related to Adolescent Intellectual Disability Sexual Behavior in SLB Bantul Regency 2018 $(n=88)$

\begin{tabular}{|c|c|c|c|}
\hline Variable & $r$ & Mean \pm SD & $p$ value \\
\hline $\begin{array}{l}\text { Providing parental } \\
\text { education }\end{array}$ & -0.126 & & $0.243 \mathrm{a}$ \\
\hline Youth knowledge & -0.280 & & $0.008 \mathrm{a}^{*}$ \\
\hline \multicolumn{3}{|l|}{ Parenting style } & \multirow{3}{*}{$0.525 \mathrm{~b}$} \\
\hline Democratic & & $78.22 \pm 19.247$ & \\
\hline Non democratic & & $82.40 \pm 21.542$ & \\
\hline \multicolumn{3}{|l|}{$\begin{array}{l}\text { Socio-economic } \\
\text { status }\end{array}$} & \multirow{3}{*}{$0.695 \mathrm{~b}$} \\
\hline Less & & $78.13 \pm 19.548$ & \\
\hline Well & & $79.89 \pm 19.485$ & \\
\hline \multicolumn{3}{|l|}{$\begin{array}{l}\text { Exposure to } \\
\text { pornographic media }\end{array}$} & \multirow{3}{*}{$0.000 \mathrm{~b}^{*}$} \\
\hline Often exposed & & $90.41 \pm 16.149$ & \\
\hline Never & & $71.31 \pm 17.719$ & \\
\hline \multicolumn{3}{|l|}{$\begin{array}{l}\text { Alcohol } \\
\text { consumption }\end{array}$} & \multirow{3}{*}{$0.150 \mathrm{~b}$} \\
\hline Consume & & $87.56 \pm 15.741$ & \\
\hline Never & & $77.68 \pm 19.639$ & \\
\hline
\end{tabular}

Source: 2018 Primary Data

Remarks: $\wedge^{\wedge} a$ : Pearson Test, $\wedge$ $b:$ Test independent sample t-test *: The value of $p<0.05$ indicates a significant mean difference.
The results of bivariate analysis between independent variables and dependent variables are shown in Table 3. The results of the analysis in Table 3 show that the giving education by parents about sexuality, parenting parents, socioeconomic status and alcohol consumption did not have a significant relationship with sexual behavior in adolescents. Different things are shown in adolescent knowledge factor $(p=0.008)$ and exposure to pornographic media $(p=0.000)$ has a significant relationship with sexual behavior in adolescents. For adolescent knowledge the value of $r=-0.280$, meaning the direction of the correlation is negative, namely the lower the respondent's knowledge, the higher the sexual behavior, while for the correlation strength statistically the value of $r$ is classified as weak $(0.2-<0.4)$.

Tabel 4: The test results of linear regression analysis of adolescent sexual behavior of intellectual disabilities in SLB Bantul Regency $2018(n=80)$

\begin{tabular}{|c|c|c|c|c|c|}
\hline & Model & B & $\beta$ & p value & $\begin{array}{c}\text { adjuste } \\
d R^{2}\end{array}$ \\
\hline 1 & Constants & 149.132 & & & \multirow{5}{*}{0.308} \\
\hline & $\begin{array}{l}\text { Alcohol } \\
\text { consumption }\end{array}$ & 3.875 & 0.061 & 0.529 & \\
\hline & $\begin{array}{l}\text { Pornography } \\
\text { Media Exposure }\end{array}$ & -20.545 & -0.518 & 0.000 & \\
\hline & $\begin{array}{l}\text { Youth } \\
\text { Knowledge }\end{array}$ & -2.144 & -0.315 & 0.001 & \\
\hline & $\begin{array}{l}\text { Giving Parent } \\
\text { Education }\end{array}$ & -0.234 & -0.095 & 0.292 & \\
\hline \multirow[t]{4}{*}{2} & Constants & 153.802 & & & \multirow{4}{*}{0.313} \\
\hline & $\begin{array}{l}\text { Pornography } \\
\text { Media Exposure }\end{array}$ & -19.698 & -0.496 & 0.000 & \\
\hline & $\begin{array}{l}\text { Youth } \\
\text { Knowledge }\end{array}$ & -2.101 & -0.309 & 0.001 & \\
\hline & $\begin{array}{l}\text { Giving Parent } \\
\text { Education }\end{array}$ & -0.223 & -0.091 & 0.312 & \\
\hline \multirow[t]{3}{*}{3} & Constants & 139.406 & & & \multirow{3}{*}{0.313} \\
\hline & $\begin{array}{l}\text { Pornography } \\
\text { Media Exposure }\end{array}$ & -19.888 & -0.501 & 0.000 & \\
\hline & $\begin{array}{l}\text { Youth } \\
\text { Knowledge }\end{array}$ & -2.124 & -0.312 & 0.001 & \\
\hline
\end{tabular}

Description:B: Constants; $\beta$ : Beta value; $p$ value $<0.05$ indicates significance.

Table 4 shows the results of linear regression analysis, which in model 3 shows that there are two variables related to adolescent sexual behavior in intellectual disabilities in SLB of Bantul Regency, namely exposure to pornographic media and adolescent knowledge. Adjusted R square score in model 3 is 0.313 , which means that exposure to pornographic media and adolescent knowledge contributes $31.3 \%$ in the score of 
adolescent sexual disability to intellectual behavior, while $68.7 \%$ is related to other factors. Exposure to pornographic media $(p=0.000 ; \beta=-0.501)$ has a significance value and a correlation that is stronger than the knowledge of adolescents $(p=0.001 ; \beta=-0.312$ ). This means that exposure to pornographic media is the most dominant variable associated with adolescent sexual behavior in intellectual disabilities.

\section{DISCUSSION}

Sexual behavior is all behavior driven by sexual desire, both with the opposite sex and same-sex (Akrami \& Davudi, 2014). About $7.69 \%$ of children with intellectual disabilities were found to be sexually abused (Akrami \& Davudi, 2014). A similar problem was reported by Tsuda et al., (2017) in his research conducted in Yogyakarta that the most common problem of sexual behavior in children with intellectual disabilities was touching their sexual organs in public areas $(69.1 \%)$, kissing other people in the public area (48.9\%), other behavioral problems namely affection hugs with the opposite sex (36.2\%). These sexual behaviors were also found in this study as many as 64 students $(72.7 \%)$ had high-risk sexual behavior. This was confirmed by Akrami (2014) who conducted a study in Iran which showed that children with intellectual disabilities had some sexual problems, such as public masturbation, sexual arousal, and severe sexuality against the opposite sex, the behavior was more prominent in adolescents with disabilities intellectual than normal teenagers.

Based on the results of this study, the most dominant factor associated with adolescent sexual behavior in intellectual disabilities is exposure to pornographic media. The results of this study are different from the research conducted by Luder et al., (2009) which states that exposure to pornographic media on adolescents who access intentionally or not, is not related to risky sexual behavior. The intended sexual behavior is the desire to have sexual relations and have many sexual partners. Differences occur because the age of the respondents in each study is different. Luder et al., (2009) conducted research on respondents with adulthood, while researchers here conducted research on respondents in their teens. This can be explained that the majority of respondents in this study were late adolescents $(>17$ years). According to the Adolescent Sexuality Planned Parenthood Federation of Adolescent in 2001, at this stage adolescents have experienced full physical changes like adults, they have clear sexual behavior and begin to develop in a relationship where sexual development is accompanied by a psychological development period one so vulnerable to exposure to pornographic media.

This is supported by research conducted by Lou et al., (2012) explaining that there is a significant relationship between consumption of porographic media and the tendency to behave sexually in adolescents. Paquette et al., (2018) also explained that the factors that influence sexual behavior in high school students are exposure to pornographic media, peers, attitudes, parents and religion. The most dominant factor affecting the sexual behavior of high school students is exposure to pornographic media. In Nigeria, Arulogun, Ogbu \& Dipeolu, (2016) explained that communication, parental education, parental knowledge, and access to internet media influence the sexual behavior of Primary School and Secondary School students. Internet media access is the most powerful factor influencing students' sexual behavior.

Uncontrolled exposure to mass media and the internet can have a negative impact on sexual behavior (Asekun et al., 2014). In this study it was found that there was a significant relationship between exposure to pornographic media and adolescent sexual behavior in intellectual disabilities. There were 34 students who were often exposed to pornography and among 34 students, 33 students were proven to have risky sexual behavior. This is similar to the research conducted by Kaljee (2011) which explains that there is a meaningful relationship between exposure to pornography and adolescent sexual behavior. The higher the exposure to pornography happens, the worse the sexual behavior of teenagers. Not only that, the encouragement and exposure of the media resulted in adolescents with intellectual disabilities having difficulty in controlling their sexual behavior in order to remain in accordance with the values of cultural norms that apply in society (Dionne \& Dupras, 2014). Another thing that can be done in overcoming the problem of sexual behavior in children with intellectual disability is to conduct pornographic management coordination. The more pornographic information obtained by children, the more sexual problems experienced by children (McKibbin, Humphreys \& Hamilton, 2017).

Based on this study there is a significant relationship between adolescent knowledge about sexuality towards adolescent sexual behavior in intellectual disabilities. This result is similar to the research conducted by 
Kucuk, Platin \& Erdem (2017), that there is a meaningful relationship between knowledge and sexual behavior in adolescents, each of which explains that knowledge has a correlation that were negative and strong, meaning that the lower the teen's knowledge about sexuality, the higher the sexual behavior. This result is supported by a survey conducted by WHO in several countries which shows that good and correct information obtained by adolescents can reduce reproductive problems in adolescents. Thus, it can be said that the higher the level of adolescent knowledge, the better the behavior, because knowledge or cognitive is a domain that is very important for the formation of one's actions (overt behavior). This is similar to what happened in this study, among others, in the knowledge questionnaire there were 23 students who answered incorrectly regarding menstruation and 23 students did not understand about the menstrual cycle, while there were 32 students who did not understand the signs of akil baliq, so it was concluded that adolescent knowledge about sexuality was still lacking.

In this study there are two factors related to sexual behavior, namely exposure to pornographic media and knowledge of adolescents. The low level of adolescent's knowledge about sexuality and the high exposure to pornography media are influenced by many things, among others, adolescents with intellectual disabilities tend to have self-efficacy in the medium to low range, which ultimately makes them unable to refuse deviant actions. In acting, they cannot consider future risks because mentally they are still like children, the most important thing is that they get satisfaction and are more likely to be unable to be responsible for the actions they have done (Asekun et al., 2014). The level of their mental abilities also influences the form of his sexual behavior, the lower his mental abilities, the more open, direct and spontaneous reactions, because their instinctive impulses are not controlled and controlled by selfawareness governed by their intelligence functions (McKibbin et al., 2017). Other influences according to Arulogun (2016), namely adolescents with intellectual disabilities are easily affected and imitate other people's actions that are not particularly good about sexual behavior. Such conditions are possible for adolescents with intellectual disabilities to behave abnormal sexually who still follow momentary pleasures and are unable to be responsible and unable to think mature in the long run, so problems arise in their sexual behavior. The results of the research prove that adolescents with mental disabilities have difficulty controlling themselves, one of which is controlling their sexual desires. They also have sexual desires towards the opposite sex, but because their conditions are sluggish intellectually, it makes difficult for them to understand the values and norms that exist in society, especially if they are not taught correctly and repeatedly so that they find it difficult to distinguish between what they can and cannot do.

Based on this study, there is no relationship between giving education by parents about sexuality toward sexual behavior in adolescents. The lack of education provided by parents is influenced by the lack of parents' knowledge about reproductive health and sexuality, therefore there is a need for counseling on reproductive health and sexuality by local health workers or by teachers. This was confirmed by the research of Clatos \& Asare (2016) which reported that training provided to parents about reproductive health could change the communication behavior and knowledge of parents, and after being applied by parents it was proven to increase knowledge about sexual education in children with disabilities. Based on this study, there is no relationship between parenting style on sexual behavior in adolescents with intellectual disabilities. It can be seen that in this study, the majority of parenting style are democratic parenting, as many as 78 parents $(88.6 \%)$. Sociodemographic characteristics and the availability of social support also greatly influence the quality of care that parents have with children with intellectual disabilities (Paquette et al., 2018). This is reinforced by the study of Huebner (2003) who explained that greater sexual behavior was found in adolescents who felt the parenting style was non-authoritative compared to the authoritative parenting style. However Huebner (2003) explained the opposite, namely teenagers with parenting permissive and authoritarian parents were more likely to have heavy sexual behavior.

Based on this study, there was no association between alcohol consumption and sexual behavior in adolescents with intellectual disabilities. This can be explained that the majority of adolescents do not consume alcohol as much as 79 students (89.8) so that teenagers with disabilities do not behave aggressively, or cannot control themselves which can cause them to do negative things. This is not in accordance with the results of research conducted by Muchimba et al., (2013) which explains that alcohol users have a higher risk of sexual behavior than those who do not consume alcohol. Huebner (2003) also explained that the use of 
certain substances by adolescents is also a factor associated with adolescent sexual behavior, adolescents who use certain drugs will have a tendency 1.6 times greater for heavy sexual behavior.

Based on this study, there is no relationship between socioeconomic status of sexual behavior in adolescents with intellectual disabilities. In this study the majority of respondents' socio-economic status was lacking as many as 60 students (68.2). This is different from Raudsepp (2007) research which explains that adolescents with low socioeconomic status show high sexual behavior, epidemiologically high sexual behavior occurs 1.5 times in groups of adolescents with low social status compared to adolescents with high social status. Other research also explains that with a low family economy, adolescents tend to have premarital sex so that their partners can fulfill everything they want (Strommen \& Mates, 2004). This difference can occur because the measurement of socio-economic status used by researchers is different, in this study the measuring instrument used is total family income, while Raudsepp (2007) uses a measuring instrument that measures deeper related to socio-economic status including income, expenditure, belongings including vehicles and father's existence.

\section{CONCLUSION}

In this study there is a relationship between adolescent knowledge about sexuality and exposure to pornographic media with sexual behavior in adolescents with intellectual disabilities in SLB Bantul Regency, Yogyakarta. Of the two factors, the exposure factor of pornographic media is the most dominant factor influencing sexual behavior in adolescents with intellectual disabilities in the SLB of Bantul Regency, Yogyakarta. Future research is expected to combine quantitative and qualitative research methods (mixedmethod) to obtain more complete and detailed data on adolescent sexual behavior. The factors that influence sexual behavior in this study together only affect $31.3 \%$ of adolescent sexual behavior in intellectual disabilities and the remainder is influenced by factors outside of this study. Further research is needed to identify other factors that have not been studied such as normal sibling ownership, peer influence, religious observance, and selfcontrol.

\section{Conflict of Interests}

The authors declare that they have no conflict of interest

\section{ACKNOWLEDGMENTS}

This research was supported by Sri Hartini, S.Kep., Ns., M.Kes., Ph.D, Dr. Dra. Budi Wahyuni, M.M.,M.A, all lecture of Faculty of Medicine Public Health and Nursing, Gadjah Mada University, all lecture of SLB in Yogyakarta. Authors wish to thank those who were closely involved in this study. This research uses personal funds and is not financed by any agency.

\section{REFERENCES}

Akrami, L. \& Davudi, M. (2014). Comparison of Behavioral and Sexual Problems between Intellectually Disabled and Normal Adolescent Boys during Puberty in Yazd, Iran. Iranian Journal of Psychiatry and Behavioral Sciences, $8(2)$, pp $68-74$.

Arulogun, O.S., Ogbu, I.A. \& Dipeolu, I.O. (2016). Influence of internet exposure on sexual behaviour of young persons in an urban district of Southwest Nigeria. The Pan African Medical Journal, 25.

Asekun-Olarinmoye, O.S., Asekun-Olarinmoye, E.O., Adebimpe, W.O. \& Omisore, A.G. (2014). Effect of mass media and Internet on sexual behavior of undergraduates in Osogbo metropolis, Southwestern Nigeria. Adolescent Health, Medicine and Therapeutics, 5, pp 15-23.

Atienzo, E.E., Walker, D.M., Campero, L., Lamadrid-Figueroa, H. \& Gutiérrez, J.P. (2009). Parent-adolescent communication about sex in Morelos, Mexico: does it impact sexual behaviour? The European Journal of Contraception \& Reproductive Health Care, 14(2), pp 111-119.

Chalmers, H., Tyrer, P. \& Aggleton, P. (2006). Sex and relationships education in schools - Evaluation of a pilot programme for the certification of community nurses. Health Education Journal, 65(1), pp 28-40. 
Clatos, K. \& Asare, M. (2016). Sexuality Education Intervention for Parents of Children with Disabilities: A Pilot Training Program. American Journal of Health Studies, 31(3), pp 151-162.

Dionne, H. \& Dupras, A. (2014). Sexual health of people with an intellectual disability: An ecosystem approach. Sexologies, 23(4), e85-e89.

Huebner, A.J. \& Howell, L.W. (2003). Examining the relationship between adolescent sexual Risk-Taking and perceptions of monitoring, communication, and parenting styles. Journal of Adolescent Health, 33(2), pp 71-78.

Kaljee, L.M., Green, M., Lerdboon, P., Riel, R., Pham, V., Ha, N.T., Minh, T.T., Li, X., Chen, X. \& Stanton, B. (2011). Parent-Youth communication and concordance between parents and adolescents on reported engagement in social relationships and sexually intimate behaviors in Hanoi and Khanh Hoa Province, Vietnam. Journal of Adolescent Health, 48(3), pp 268-274.

Kellogg, N.D. (2009). Clinical Report--The Evaluation of Sexual Behaviors in Children. American Academy of Pediatrics, 124(3), pp 992-998.

Kementerian Kesehatan RI. (2014). Profil Kesehatan Indonesia. Bab V Pelayanan Kesehatan Anak Dengan Disabilitas. Halaman 129. Jakarta.

Kim, H.Y., Park, M. \& Lee, E. (2018). A cross-sectional survey of relationships between sexual knowledge, sexual attitudes, and reproductive health behaviour among female university students. Contemporary Nurse, 54(6), pp 640-650.

Kucuk, S., Platin, N. \& Erdem, E. (2017). Increasing awareness of protection from sexual abuse in children with mild intellectual disabilities: An education study. Applied Nursing Research, 38, pp 153-158.

Lou, C., Cheng, Y., Gao, E., Zuo, X., Emerson, M.R. \& Zabin, L.S. (2012). Media's Contribution to Sexual Knowledge, Attitudes, and Behaviors for Adolescents and Young Adults in Three Asian Cities. Journal of Adolescent Health, 50(3), S26-S36.

Luder, M.-T., Pittet, I., Berchtold, A., Akré, C., Michaud, P.-A. \& Surís, J.-C. (2011). Associations Between Online Pornography and Sexual Behavior Among Adolescents: Myth or Reality? Archives of Sexual Behavior, 40(5), pp $1027-1035$.

McKibbin, G., Humphreys, C. \& Hamilton, B. (2017). "Talking about child sexual abuse would have helped me": Young people who sexually abused reflect on preventing harmful sexual behavior. Child Abuse \& Neglect, 70, 210-221.

Muchimba, M., Haberstick, B.C., Corley, R. P. \& McQueen, M.B. (2013). Frequency of Alcohol Use in Adolescence as a Marker for Subsequent Sexual Risk Behavior in Adulthood. Journal of Adolescent Health, 53(2), pp 215-221.

Paquette, G., Bouchard, J., Dion, J., Tremblay, K.N., Tourigny, M., Tougas, A.-M. \& Hélie, S. (2018). Factors associated with intellectual disabilities in maltreated children according to caseworkers in child protective services. Children and Youth Services Review, 90, pp 38-45.

Raudsepp, L. (2007). The relationship between socio-economic status, parental support and adolescent physical activity. Acta Paediatrica, 95(1), pp 93-98.

Riset Kesehatan Dasar (Riskesdas) (2013). Badan Penelitian dan Pengembangan Kesehatan RI. Bab 3 Hasil dan Pembahasan Status Disabilitas. Halaman 123. Jakarta.

Stein, S., Kohut, T. \& Dillenburger, K. (2017). The Importance of Sexuality Education for Children with and without Intellectual Disabilities: What Parents Think. Sexuality and Disability, 36(2), pp 141-148.

Strommen, L.T. \& Mates, B.F. (2004). Learning to Love Reading: Interviews with Older Children and Teens. Journal of Adolescent \& Adult Literacy, 48(3), pp 188-200. 
Tsuda, S., Hartini, S., Hapsari, E. D. \& Takada, S. (2017). Sex Education in Children and Adolescents with Disabilities in Yogyakarta, Indonesia From a Teachers' Gender Perspective. Asia Pacific Journal of Public Health, 29(4), pp 328-338.

World Health Organization (2014). Health Topics. Noncommunicable Diseases. Mental Health. Children's Right to Family Life. Intellectual Disability. Retrieved from: https://www.euro.who.int/en/health-topics/noncommunicablediseases/mental-health/news/news/2010/15/childrens-right-to-family-life/definition-intellectual-disability\#: :text $=$ Intellectual $\% 20$ disability $\% 20$ means $\% 20 \mathrm{a} \% 20$ significantly,a $\% 201$ asting $\% 20$ effect $\% 20$ on $\% 20$ development.

Wilson, E. K., Dalberth, B. T., Koo, H. P. \& Gard, J. C. (2010). Parents' Perspectives on Talking to Preteenage Children About Sex. Perspectives on Sexual and Reproductive Health, 42(1), pp 56-63.

Wissink, I. B., van Vugt, E., Moonen, X., Stams, G.-J. J. M., \& Hendriks, J. (2015). Sexual abuse involving children with an intellectual disability (ID): Anarrative review. Research in Developmental Disabilities, 36, pp 20-35. 